\title{
Dynamics of dissolved organic carbon from aerobic and anaerobic decomposition of Typha domingensis Pers. and Eleocharis interstincta (Vahl) Roem. \& Schult. in a tropical coastal lagoon
}

Dinâmica do carbono orgânico dissolvido na decomposição aeróbia e anaeróbia de Typha domingensis Pers. e Eleocharis interstincta (Vahl) Roem. \& Schult. em uma lagoa costeira tropical

André Luiz dos Santos Fonseca ${ }^{1}$, Claudio Cardoso Marinho ${ }^{2}$ and Francisco de Assis Esteves ${ }^{2}$

${ }^{1}$ Instituto Federal de Educação, Ciência e Tecnologia do Rio de Janeiro, Campus Realengo, Rua Carlos Wenceslau, 343, CEP 21715-000, Rio de Janeiro, RJ, Brazil e-mail: andre.fonseca@ifrj.edu.br

${ }^{2}$ Laboratório de Limnologia, Departamento de Ecologia, Universidade Federal do Rio de Janeiro - UFRJ, CEP 21941-590, Rio de Janeiro, RJ, Brazil e-mail: clcamar@biologia.ufrj.br, festeves@biologia.ufrj.br

\begin{abstract}
Aim: The aim of this study was to evaluate the initial stage of decomposition of two aquatic macrophytes (Typha domingensis and Eleocharis interstincta) under aerobic and anaerobic conditions; Methods: The samples of aquatic macrophytes and water were collected in Cabiúnas lagoon, Rio de Janeiro, Brazil. In the experiment 1 mineralization chambers were prepared with fresh plant fragments and water from the lagoon in aerobic and anaerobic conditions. $\mathrm{DOC}$ and $\mathrm{CO}_{2}$ formation and $\mathrm{O}_{2}$ consumption were measured during 30 days. In the experiment 2 mineralization chambers were prepared with aquatic macrophytes leachate and glucose for each experimental condition. $\mathrm{CO}_{2}$ formation and $\mathrm{O}_{2}$ consumption were measured during 1 day; Results: In experiment 1 DOC concentrations in T. domingensis decomposition were higher. Despite this, $\mathrm{CO}_{2}$ formation was more efficient in E. interstincta decomposition. The oxygen consumption increased in the beginning of decomposition and tended to stabilize towards the end. The $\mathrm{O} / \mathrm{C}$ values increased in the beginning of decomposition and decreased thereafter. In experiment 2, aerobic decomposition presented higher $\mathrm{CO}_{2}$ formation. E. interstincta leachate presented higher $\mathrm{CO}_{2}$ concentration than T. domingensis; Conclusion: Our results showed that aerobic decomposition in the initial stages is higher only in T. domingensis mineralization. Oxygen consumption varies according to the alterations in the chemical composition of the detritus. The formation of $\mathrm{CO}_{2}$ from T. domingensis and E. interstincta decomposition in the water column is irrelevant in Cabiúnas Lagoon. The low DOC release from fresh aquatic macrophytes detritus indicates that particulate organic matter mineralization is the main route of $T$. domingensis and E. interstincta decomposition.
\end{abstract}

Keywords: DOC, $\mathrm{CO}_{2}$, oxygen consumption, aquatic macrophytes, detritus mineralization.

Resumo: Objetivo: O objetivo deste estudo foi avaliar o estágio inicial de decomposição de duas macrófitas aquáticas (Typha domingensis e Eleocharis interstincta) em condiçôes aeróbias e anaeróbias; Métodos: As amostras de macrófitas aquáticas e água foram coletadas na lagoa Cabiúnas, Rio de Janeiro, Brasil. No experimento 1 câmaras de mineralização foram preparadas com fragmentos vegetais frescos e água da lagoa para cada condição (aeróbia e anaeróbia). A formação de DOC e de $\mathrm{CO}_{2}$ e o consumo de $\mathrm{O}_{2}$ foram medidos durante 30 dias. No experimento 2 câmaras de mineralização foram preparadas com lixiviados de macrófitas aquáticas e glicose em cada condição experimental (aeróbia e anaeróbia). A formação de $\mathrm{CO}_{2}$ e o consumo de $\mathrm{O}_{2}$ foram medidos durante 1 dia; Resultados: No experimento 1 as concentraçôes de COD na decomposição de $T$. domingensis foram maiores. Apesar disso, a formação de $\mathrm{CO}_{2}$ foi mais eficiente na decomposição de E. interstincta. O consumo de oxigênio aumentou no começo da decomposição dos detritos e tenderam a estabilizar no final. Os valores de $\mathrm{O} / \mathrm{C}$ aumentaram no início da decomposição e diminuíram em seguida. No experimento 2 , a decomposição aeróbia apresentou maior formação de $\mathrm{CO}_{2}$ em todos os recursos. O lixiviado de E. interstincta apresentou maior concentração de $\mathrm{CO}_{2}$ do que o de T. domingensis em ambas as condiçóes; Conclusão: Os resultados mostraram que a decomposição aeróbia inicial é maior em $T$. domingensis. $\mathrm{O}$ consumo de oxigênio varia de acordo com as alteraçóes químicas dos detritos. A formação de $\mathrm{CO}_{2}$ na decomposição de T. domingensis e E. interstincta é irrelevante na Lagoa Cabiúnas. A baixa liberação de DOC dos detritos indicam que a mineralização da matéria orgânica particulada é a principal via de decomposiçáo de T. domingensis e E. interstincta.

Palavras-chave: $\mathrm{COD}, \mathrm{CO}_{2}$, consumo de oxigênio, macrófitas aquáticas, mineralização do detrito. 


\section{Introduction}

Coastal lagoons are among the most productive aquatic ecosystems on the planet (Knoppers, 1994). In the littoral zone of these ecosystems, aquatic macrophytes communities usually find propitious conditions for growth, being the main source of autochthonous detritus as they prevail in the total biomass of littoral organisms, and they are only rarely available as direct food of consumers (Pieczynska, 1993). In tropical aquatic systems, aquatic macrophytes decomposition sustains the food chains and the energy flow and controls the littoral nutrient cycles (Schlickeisen et al., 2003). However, incomplete decomposition of aquatic detritus usually leads to accumulation and increases carbon storage (Costantini et al., 2009; Geurts et al., 2010). Therefore, studies approaching the main factors that influence aquatic macrophytes decomposition in costal lagoons are critical for achieving a fundamental understanding of carbon cycling.

Among the factors that control decomposition processes, detritus quality has a major role (Chimney and Pietro, 2006; Lecerf et al., 2007; Geurts et al., 2010). The structural heterogeneity of detritus, due to the labile and refractory compounds, is one way to infer the detritus quality (Bianchini Junior, 2003; Bianchini Junior and Cunha-Santino, 2008). The metabolic routes associated with degradation of labile and refractory compounds of aquatic macrophytes proceeds in three distinct phases: (a) an initial rapid loss due to leaching, (b) the physical fragmentation of the detritus and the chemical modifications due to digestion process, and (c) catabolism of structural components (Webster and Benfield, 1986). The differences in detritus decomposition rates usually result from interspecific variations in aquatic macrophytes (Li et al., 2012). In general, aquatic macrophytes with more structural carbon (fibrous) decompose faster than those more succulent (DeBusk and Dierberg, 1984; Janssen and Walker, 1999). These differences allow a general classification according to the rate of decomposition, where the submerged aquatic macrophytes are decomposed faster than floating plants and these faster than the emergent species (Chimney and Pietro, 2006).

Physical and chemical conditions surrounding plant detritus during decomposition are additional factors that control macrophytes decomposition (Alvarez and Guerrero, 2000; Chimney and Pietro,
2006; Lecerf et al., 2007). In an aquatic ecosystem, detritus decomposition is significantly influenced by oxygen availability (Moore et al., 1992; McLatchey and Reddy, 1998; Bianchini Junior, 2003). It has been reported that aerobic processes act on a larger spectrum of organic matter and is accomplished by a wide group of microorganisms, which convert many components of the organic matter quickly as $\mathrm{CO}_{2}$ and cell substances, while those less susceptible to microbial attack persist (Reddy and Sacco, 1981; Bianchini Junior, 2003). On the other hand, anaerobic bacteria operate at a much lower energy level and anaerobic decomposition is much less efficient (Campbell, 1978; Reddy and Sacco, 1981). However, some studies comparing detritus decomposition in both conditions presented conflicting results. For instance, the decomposition of dissolved organic matter (DOM) released from freshwater aquatic macrophytes was faster under aerobic condition, whereas the rate of conversion of particulate organic matter (POM) to carbon dioxide $\left(\mathrm{CO}_{2}\right)$ and/or DOM was regulated primarily by temperature, tissue nitrogen, and fiber content (Godshalk and Wetzel, 1978a; 1978b). On other study, mineralization of leachable and easily hydrolysable compounds from fresh plant detritus was equally fast under aerobic and anaerobic conditions. When structural components dominate the remaining particulate, anaerobic processes were hampered by inefficient and slow bacterial hydrolysis of structurally complex macromolecules (Kristensen et al., 1995). When oxygen is available, the relation between the amounts of oxygen consumed per carbon oxidized is referred to as stoichiometric ratio (Brezonik, 1993). Stoichiometry evolves over time, according to the predominance of labile or refractory compounds oxidation (Cunha-Santino et al., 2004; Peret and Bianchini Junior, 2004). Considering the importance of decomposition process to carbon cycling in aquatic ecosystems, this research hypothesized that detritus decomposition of two emergent aquatic macrophytes (Typha domingensis Pers. and Eleocharis interstincta (Vahl) Roem. \& Schult.) is higher in aerobic condition. To test this hypothesis, this research aimed to describe and discuss the initial stage of decomposition of the two emergent aquatic macrophytes under aerobic and anaerobic conditions in laboratory, through particulate organic matter (POC) content, dissolved organic carbon (DOC) and carbon dioxide $\left(\mathrm{CO}_{2}\right)$ formation, and oxygen consumption. 


\section{Material and Methods}

\subsection{Study area}

Cabiúnas Lagoon (Figure 1) is located on the Restinga de Jurubatiba National Park at Macaé, in the Northern region of Rio de Janeiro State $\left(22^{\circ}\right.$ $24^{\prime} S$ and $41^{\circ} 42^{\prime}$ W).

The lagoon presents average values of oxygen concentration of $7.18 \mathrm{mg} \mathrm{L}^{1}$, salinity of $1.1 \mu \mathrm{s}$, conductivity $1.3 \mathrm{mS} \mathrm{cm} \mathrm{cm}^{-1}$ and disappearance of the Secchi disk at $1.8 \mathrm{~m}$ (Enrich-Prast et al., 2004). Farjalla (1998) observed limitation of bacterial growth in the water simultaneously by the carbon, nitrogen and phosphorus. Phytoplankton primary production in Cabiúnas Lagoon is low (0.93 to $11.23 \mathrm{mg} \mathrm{C} \mathrm{m}^{-3} \mathrm{~d}^{-1}$ ) (Roland, 1998). On the other hand, the small depth (mean depth of $2.37 \mathrm{~m}$ ) and large perimeter/volume ratio (Panosso et al., 1998) enable the widespread development of aquatic macrophytes communities in its margins, being the main source of organic matter to this ecosystem (Faria and Esteves, 2000). The emergent aquatic macrophytes Typha domingensis and Eleocharis interstincta were used in this study, since they form dense stands in the littoral region (Henriques et al., 1988)

\subsection{Sampling procedures and experimental design}

Experiment 1: Leaves of $T$. domingensis and $E$. interstincta in senescence phase were collected before drape over the water column in March 2001. The water samples used in the assays were collected in polyethylene bottles and brought immediately to the laboratory to set up the incubations. In the laboratory, we measured the fresh weight (FW) of the plants. 10 pieces of $0.3 \mathrm{~g}$ were separated for drying at 70 degrees for 72 hours, to obtain a ratio between fresh weight and dry weight (DW). We consider the content of POC in the detritus of $T$. domingensis of $43.7 \%$ DW, according Farjalla et al. (1999),
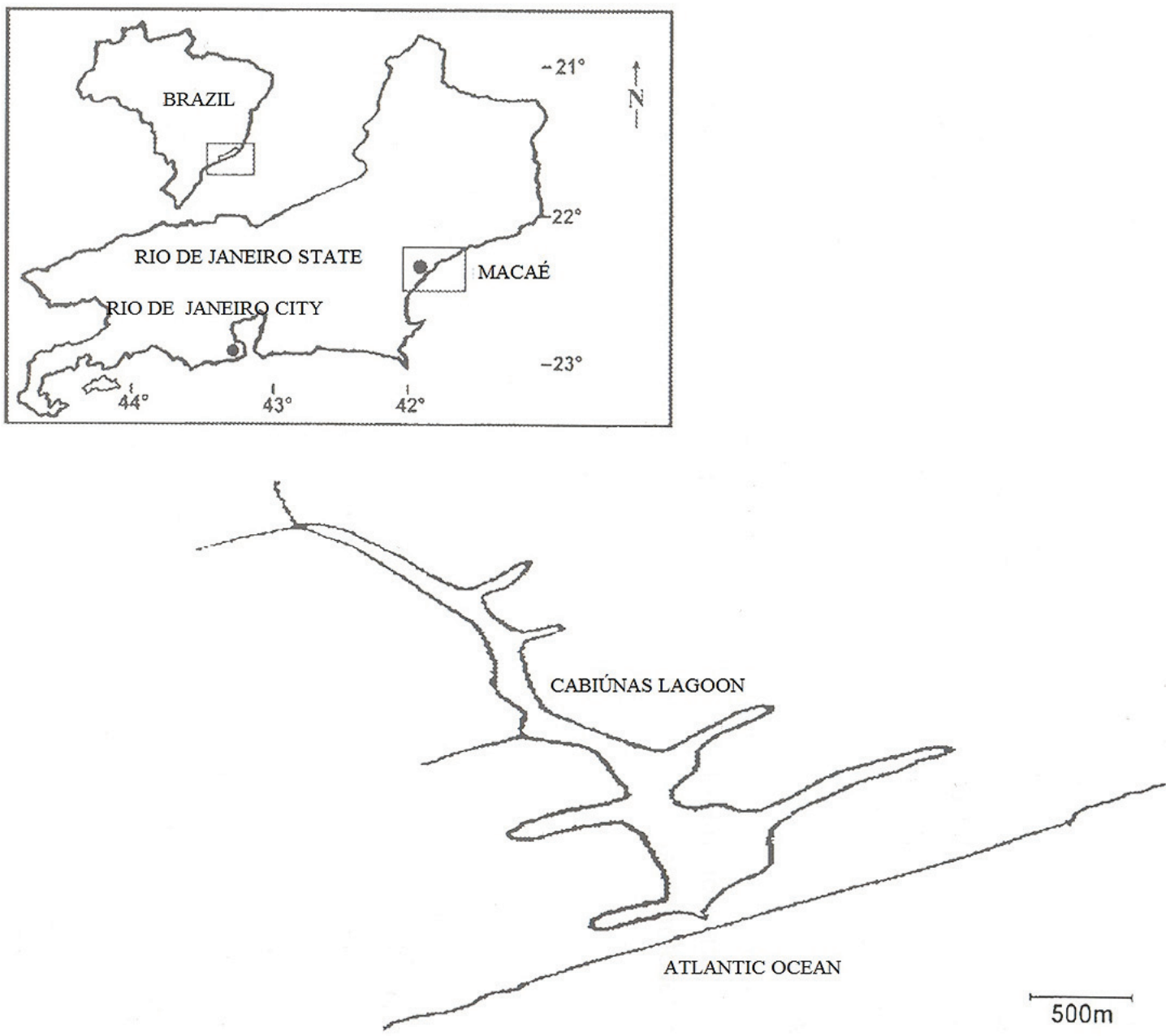

Figure 1. Schematic map of Cabiúnas lagoon location on the Restinga de Jurubatiba National Park at Macaé, in the Northern region of Rio de Janeiro State (22 $24^{\prime} \mathrm{S}$ and $\left.41^{\circ} 42^{\prime} \mathrm{W}\right)$. 
and $41.0 \%$ DW of the detritus of E. interstincta, observed by Amado et al. (2005). The water from the lagoon was previously filtered through plankton net with mesh size of $100 \mu \mathrm{m}$ to remove organic matter from other sources such as phytoplankton and zooplankton, which could alter the results of incubations. Afterward, a fraction of water was placed in an $\mathrm{O}_{2}$ saturation condition by atmospheric air bubbling, and the another part was placed in anoxia condition by $\mathrm{N}_{2}$ bubbling. The experiment was performed in decomposition chambers, set up in $260 \mathrm{~mL}$ glass vials. Each chamber received $0.3 \mathrm{~g}$ of fresh leaf of one species containing water from the lagoon throughout its volume (bubble free) ( $\mathrm{n}=32$ for each treatment). For control, only water from the lagoon was incubated in each condition $(n=3)$. The experiment was kept for 30 days in a cultivation room in the dark and under $22 \pm 2{ }^{\circ} \mathrm{C}$. The temperature was close to the average temperature of $22.7^{\circ} \mathrm{C}$ in the lagoon from July 2000 to February 2003 (Enrich-Prast et al., 2004). On days 1, 2, 3, 4, 5, 9 and 30, four flasks per treatment were removed for measurement of DOC, $\mathrm{CO}_{2}$ and $\mathrm{O}_{2}$. After removing the flasks at day 4, it was observed that the aerobic treatment reached hypoxia $\left(\mathrm{O}_{2}\right.$ concentration $\left.\leq 2.5 \mathrm{mg} \mathrm{L}^{-1}\right)$, and all of the remaining flasks were aerated again. From the fourth day until the end of the experiment, the hypoxia in aerobic treatments was not observed. DOC and $\mathrm{CO}_{2}$ (inorganic carbon - IC) were determined by a carbon analyzer TOC-5000 (Shimadzu Co., Japan) after filtration of the samples through $0.7 \mu \mathrm{m}$ filter (GF/F, Whatman). After the measurement, the values of DOC in flasks with plants were subtracted from the DOC of control flasks (only water from the lagoon), resulting in the DOC of plants. To determine the fractions corresponding to POC, DOC and $\mathrm{CO}_{2}$ in the experiment, we subtract the values of $\mathrm{DOC}$ and $\mathrm{CO}_{2}$ concentrations from the initial values of $\mathrm{POC}$ using the following equation:

$\mathrm{POC}_{\text {fina }}=\mathrm{POC}_{\text {initia }}-\left(\mathrm{DOC}_{\text {final }}-\mathrm{DOC}_{\text {initial }}\right)-\left(\mathrm{CO}_{\text {2final }}-\mathrm{CO}_{\text {2initial }}\right)$

where $\mathrm{POC}_{\text {final }}$ is the final concentration of POC, $\mathrm{POC}_{\text {initial }}$ is the initial concentration of POC, as for DOC and $\mathrm{CO}_{2}$. Concentrations of dissolved oxygen $\left(\mathrm{mg} \mathrm{O}_{2} \mathrm{~L}^{-1}\right)$ in water were calculated from the readings with a mini-electrode OX-500 coupled to a picoammeter (Unisense). The temporal variations of stoichiometry were calculated between the consumed oxygen and the oxidized carbon $(\mathrm{O} / \mathrm{C})$ from the daily rates.

Experiment 2: In this experiment the leachate extracted from macrophytes $T$. domingensis and $E$. interstincta and glucose were incubated. The leachate was obtained according to Farjalla et al. (2009). Glucose was used as reference for labile carbon. Incubations were performed in the water of lagoon under the same conditions of experiment 1 , but only for 1 day. The final concentration in the bottles was $15 \mathrm{mg} \mathrm{C} \mathrm{L}^{-1}$ of leachate and glucose. In order to prevent nutrient limitation during glucose decomposition were added $\mathrm{NH}_{4} \mathrm{NO}_{3}$ equivalent to $50 \mu \mathrm{M}$ of $\mathrm{N}$ and $\mathrm{KH}_{2} \mathrm{PO}_{4}$ equivalent to $5 \mu \mathrm{M}$ of $\mathrm{P}$, in accordance with an N:P molar ratio of 10:1 proposed by Fagerbakke et al. (1996). At the beginning of the experiment and after $24 \mathrm{~h} \mathrm{CO}_{2}$ and $\mathrm{O}_{2}$ concentrations were measured.

\subsection{Statistical analyses}

In the experiment 1 , the mean $\mathrm{DOC}$ and $\mathrm{CO}_{2}$ concentrations were statistically analyzed through parametric repeated measures ANOVA with significance level of 0.05 . In the experiment 2 , the mean $\mathrm{CO}_{2}$ concentrations were statistically analyzed through parametric ANOVA with significance level of 0.05 .

\section{Results}

The mass of $0.3 \mathrm{~g}$ fresh weight represented 0.092 g dry weight (DW); $\mathrm{SD}=0.040$ for $T$. domingensis detritus and $0.112 \mathrm{~g}$ DW; $S D=0.044$ for the detritus of $E$. interstincta. In the aquatic macrophytes tissues, the particulate organic carbon (POC) was predominant over the soluble fractions (i.e., dissolved organic carbon - DOC). POC was 84.65 and $87.33 \%$ of initial detritus for T. domingensis in aerobic and anaerobic conditions, respectively. In detritus of $E$. interstincta, the values were 90.33 and $86.51 \%$, respectively. DOC accounted for 12.65 and $10.67 \%$ of the intact detritus in aerobic and anaerobic conditions in T. domingensis, respectively. DOC values for the detritus of $E$. interstincta were 6.96 and $10.84 \%$ under aerobic and anaerobic conditions, respectively. In detritus of T. domingensis, $\mathrm{CO}_{2}$ represented 2.70 and $2.00 \%$ of the detritus in aerobic and anaerobic conditions, respectively. To E. interstincta, the $\mathrm{CO}_{2}$ values were 2.72 and $2.65 \%$ in the aerobic and anaerobic conditions, respectively.

DOC concentrations were significantly higher $(\mathrm{p}<0.05)$ in $T$. domingensis decomposition in both conditions (Figure 2A-D). DOC showed no significant differences $(p>0.05)$ for the same detritus type in different conditions (Figure 2A-D). For all treatments, DOC concentrations showed a sudden increase in the early decomposition and a more gradual increase later (Figure 2A-D). $\mathrm{CO}_{2}$ 

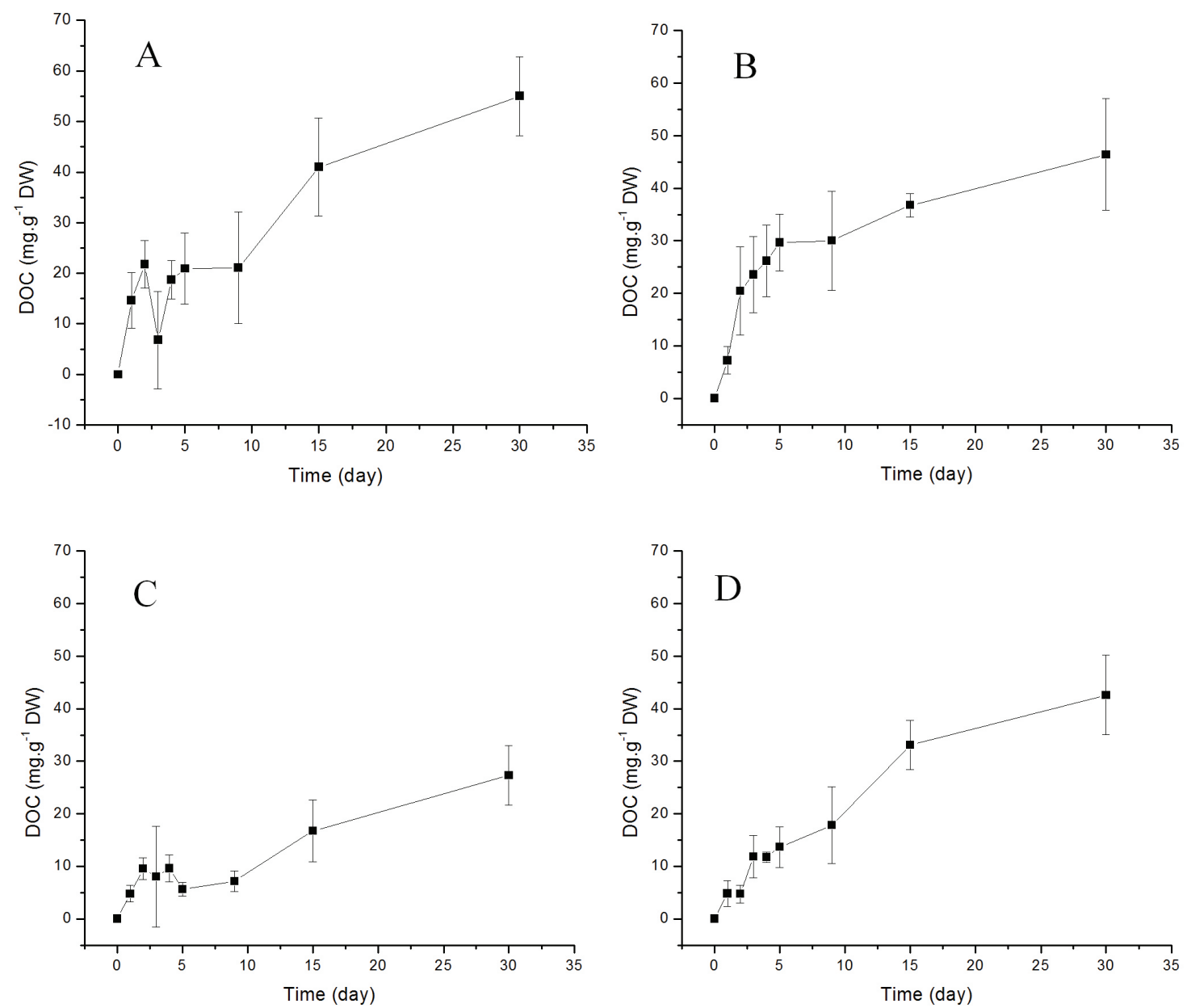

Figure 2. DOC temporal variation in aerobic (A) and anaerobic (B) decomposition of T. domingensis detritus and in aerobic (C) and anaerobic (D) decomposition E. interstincta detritus. Error bars represent \pm SD.

concentrations were higher in aerobic condition in both detritus decomposition (Figure $3 \mathrm{~A}-\mathrm{D})$, but significant differences $(\mathrm{p}<0.05)$ were observed only in $T$. domingensis decomposition. $\mathrm{CO} 2$ formation was similar between the detritus of the two species of aquatic macrophytes in aerobic condition ( $p>0.05)$ (Figure 3A and 3C). In the anaerobic condition, $\mathrm{CO}_{2}$ concentrations were significantly higher $(\mathrm{p}<$ 0.05 ) in E. interstincta decomposition (Figure 3B and 3D). The similar values of $\mathrm{CO}_{2}$ concentrations in aerobic condition and higher in the E. interstincta anaerobic decomposition occurred despite the greater DOC contribution from $T$. domingensis detritus in both conditions.

The accumulated oxygen consumption increased sharply in the beginning decomposition for both detritus and tended to stabilize towards the end of the experiment (Figure 4A-B). These results are consistent with the high initial daily rates and with the subsequent low rates (Figure $4 \mathrm{~A}-\mathrm{B}$ ). The $\mathrm{O} / \mathrm{C}$ stoichiometric ratio showed increasing values in the beginning of decomposition and then the values decreased (Figure $4 \mathrm{C}-\mathrm{D}$ ). The temporal variation of $\mathrm{O} / \mathrm{C}$ values showed small oxygen consumption per mineralized carbon at the beginning of the experiment, a further increase in these values and subsequently a decrease in the $\mathrm{O} / \mathrm{C}$ ratio.

In the experiment with glucose and leachates, aerobic decomposition was significantly higher ( $\mathrm{p}$ $<0.05$ ) than anaerobic decomposition for each resource (Figure 5). Aerobic decomposition of glucose was significantly higher $(\mathrm{p}<0.05)$ than both aquatic macrophytes leachates and $E$. interstincta leachate decomposition was significantly higher ( $\mathrm{p}$ $<0.05$ ) than T. domingensis (Figure 5). In anaerobic condition, E. interstincta leachate decomposition was significantly higher $(\mathrm{p}<0.05)$ than glucose and T. domingensis leachate decomposition (Figure 5).

\section{Discussion}

The low DOC release from aquatic macrophytes detritus in our study (Figure $2 \mathrm{~A}-\mathrm{D}$ ) indicates that 

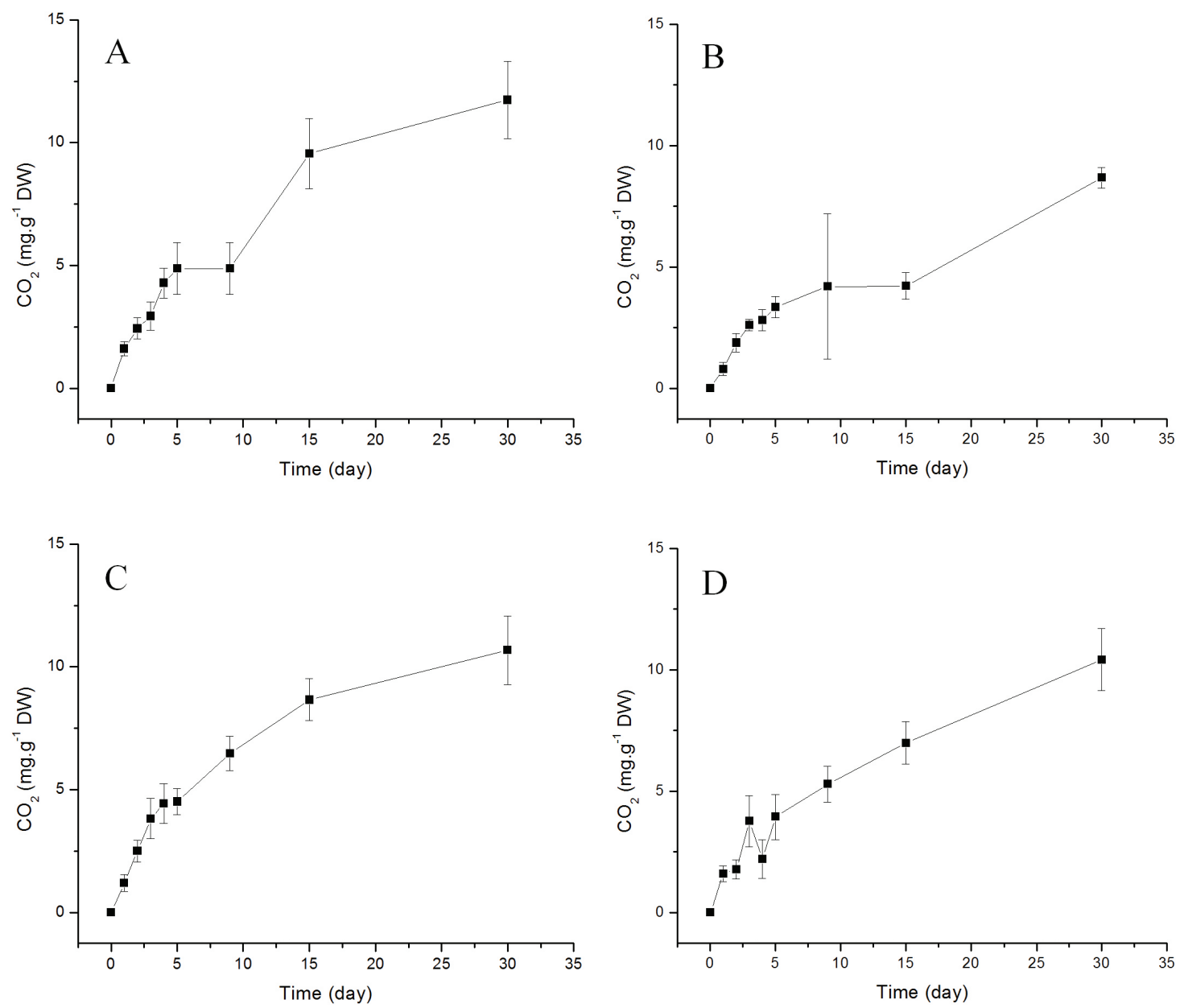

Figure 3. $\mathrm{CO}_{2}$ temporal variation in aerobic (A) and anaerobic (B) decomposition of $T$. domingensis detritus and in aerobic (C) and anaerobic (D) decomposition E. interstincta detritus. Error bars represent \pm SD.

T. domingensis and E. interstincta contribute to the ecosystem functioning mainly through particulate organic matter decomposition restricted to the original habitat of plants in the sediment from littoral region. This finding is consistent with the results observed in another study in the same ecosystem (Marinho et al., 2010). Our result is related with two main aspects considering the detritus characteristics. First, the high structural tissues (fibers) content observed in emergent aquatic macrophytes that are difficult to decompose (Farjalla et al., 1999; Bianchini Junior, 2003). Second, the proportion of initial mass loss through leaching in detritus in different phenological stages is higher in green plants, due to the higher concentrations of labile compounds of low molecular weight, in relation to senescent plants (Gonçalves et al., 2004). Brum and Esteves (2001), in a study of decomposition using green leaves of aquatic macrophytes found a high initial mass loss, which was associated with high concentrations of labile compounds present in this type of detritus. According to both aspects presented, DOC from emergent aquatic macrophytes in senescent stage represents only a minor proportion of detritus that can transcend habitat boundaries and affect the ecosystem functioning in the pelagic habitat. In contrast with our observations, Cunha-Santino and Bianchini Junior (2006) found near 10\% of DOC released in the first day of $T$. domingensis decomposition and Gopal (1984) found near 5\% of weight loss from $T$. angustifolia on the third day. These greater results can be attributed to detritus manipulation, which damage the cellular structure. In the former study, the detritus were oven-dried and fragmented (size ca. $1.5 \mathrm{~cm}$ ) and in the latter they were air dried. In our study, we used fresh detritus. This type of incubation that maintains cell integrity is closest to the release of DOC under natural conditions. Despite the low DOC release, $T$. domingensis released more DOC per gram of litter than E. interstincta in both 

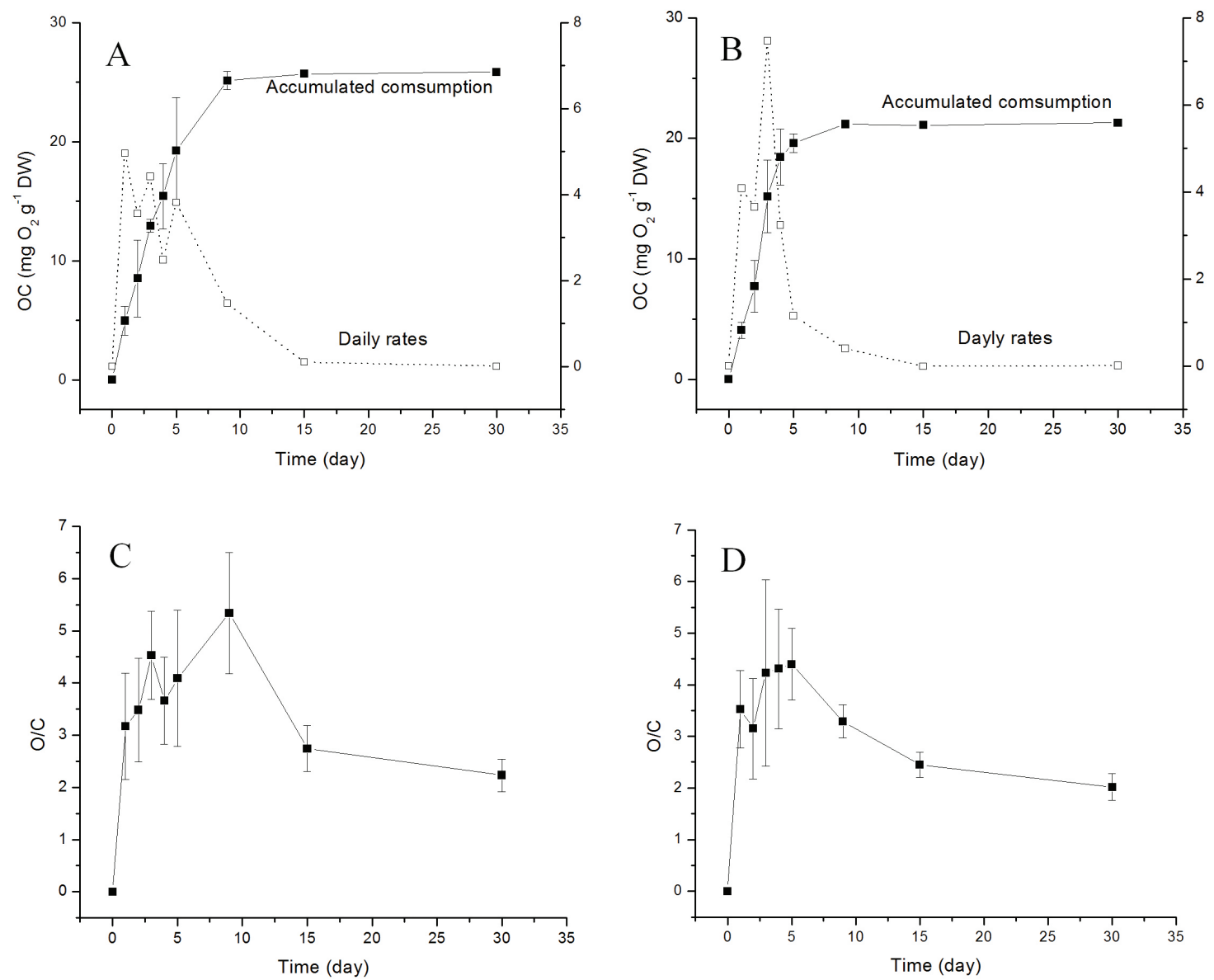

Figure 4. Temporal variation of daily rates and accumulated oxygen consumption in aerobic decomposition of $T$. domingensis (A) and E. interstincta (B) detritus. Temporal variation of $\mathrm{O} / \mathrm{C}$ stoichiometric ratio in aerobic decomposition of $T$. domingensis (C) and E. interstincta (D) detritus. Error bars represent \pm SD.

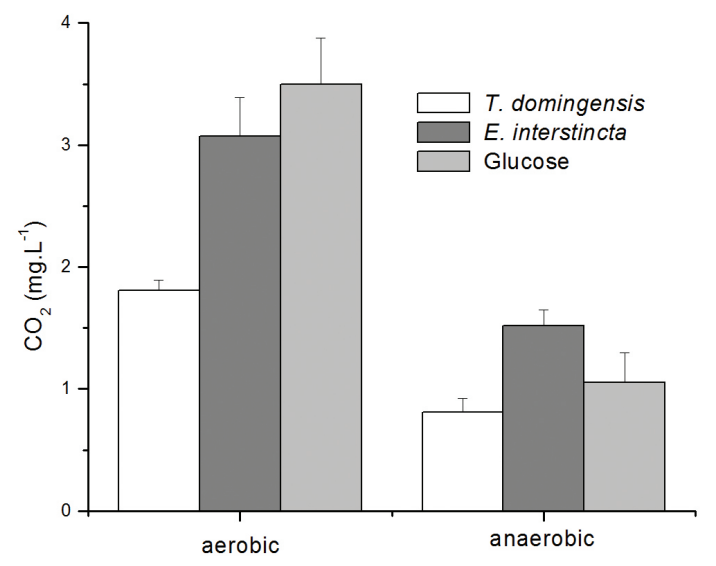

Figure 5. $\mathrm{CO}_{2}$ concentration in aerobic and anaerobic decomposition of $T$. domingensis and $E$. interstincta leachates and glucose. Error bars represent SD.

aerobic and anaerobic conditions. This finding is in accordance with other studies in which DOC released from E. cellulosa was lower than that from T. domingensis, due to the higher concentrations of water extractable substances in this detritus
(Maie et al., 2006; Qualls and Richardson, 2003). Our results indicate that $T$. domingensis leaching can be a more important autochthonous source of DOC in this freshwater ecosystem Additionally, coastal lagoons are ecosystems subjected to natural and/ or artificial water level fluctuation (Amado et al., 2005; Santos et al., 2006) and DOC release might be particularly important when coastal lagoons are rewetted after the dry season or an artificial opening and aquatic macrophytes become inundated.

In general, the formation of $\mathrm{CO}_{2}$ was higher in aerobic condition for both types of detritus (Figure 3 A-D) and the differences were greater in the aerobic mineralization of leachate (Figure 5). Possibly, the leachate supply as a whole, and consequently the release of all the labile material at the same time, resulted in a favoring of aerobic mineralization, causing increased $\mathrm{CO}_{2}$ formation in this process for all resources. On the other hand, the gradual leachate release from the fresh detritus resulted in a lower $\mathrm{CO}_{2}$ production in both conditions in the early decomposition. Hence, no significant 

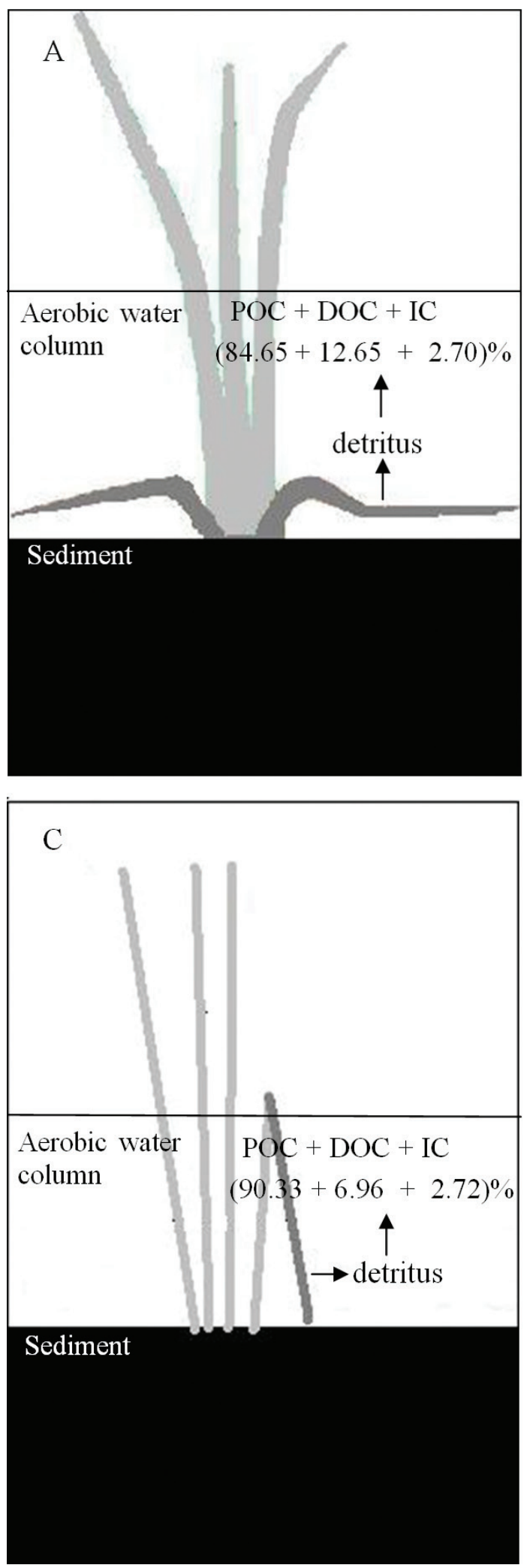
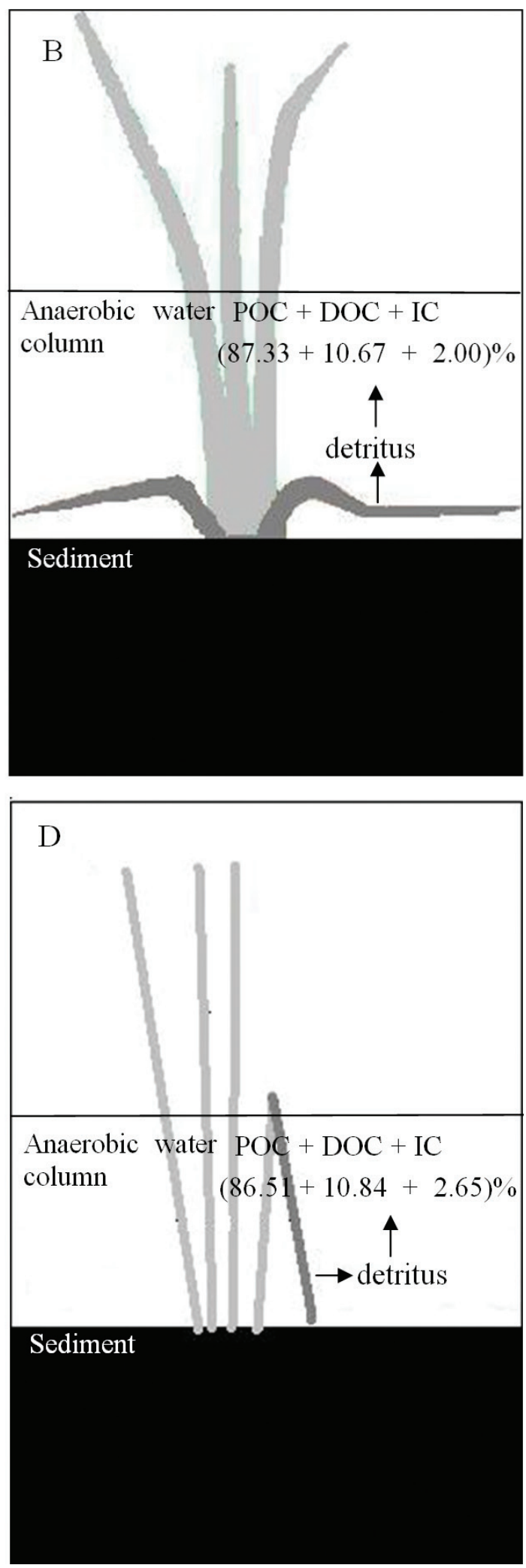

Figure 6. Scheme of the initial decomposition days of $T$. domingensis and E. interstincta detritus: T. domingensis: (A) Aerobic water column; (B) Anaerobic water column. E. interstincta: (C) Aerobic water column; (D) Anaerobic water column. 
differences were observed between the aerobic and anaerobic processes during the decomposition of detritus $E$. interstincta. These results are consistent with other studies that compared aerobic and anaerobic decomposition of aquatic macrophytes and found faster mineralization under aerobic conditions (Cunha-Santino and Bianchini Junior, 2006; Silva et al., 2011). It has been reported that aerobic processes act on a larger spectrum of organic matter and, in general, they perform faster than in anaerobic processes (Bianchini Junior, 2003). On the other hand, some studies found equally fast or greater speed in anaerobic decomposition depending on the fraction of the detritus (labile or refractory) considered (Kristensen et al., 1995; Bianchini Junior et al., 2002). Kristensen et al. (1995) suggested that the rate of decay under different redox conditions depends primarily on the age and origin and thus the chemical composition of the organic matter considered. Therefore, our hypothesis was accepted for $T$. domingensis detritus and for the leachate decomposition of both aquatic macrophytes and was rejected for E. interstincta detritus decomposition.

The temporal variation of oxygen consumption was similar to that obtained in oxygen uptake in other studies (Brum et al., 1999; Farjalla et al., 1999; Bianchini Junior et al., 2008). In the beginning, the consumption was accentuated, but then oxygen consumption rates decreased (Figure 4 A-B). Considering that the resources are structurally heterogeneous, with labile and refractory fractions (Bianchini Junior and Cunha-Santino, 2008), oxidation of labile fractions occurred in the beginning, and this generated high oxygen demands. On the other hand, reductions in the rates of oxygen consumption were associated with mineralization of the refractory fractions of particulate and dissolved organic matter. The stoichiometry between consumption of oxygen and oxidized carbon (O/C ratio) during the decomposition (Figure 4 C-D) was another methodological procedure to evaluate mineralization in this study and also showed temporal variation. According to Peret and Bianchini Junior (2004), low O/C values occur during mineralization of labile fractions in the beginning of decomposition due to the low oxygen consumption per mineralized carbon, and high $\mathrm{O} / \mathrm{C}$ values occur subsequently, during the decomposition of refractory compounds. Subsequent alterations during decomposition of refractory compounds lead to a new availability of labile compounds, decreasing the $\mathrm{O} / \mathrm{C}$ ratio again. Our study showed this pattern of variation of $\mathrm{O} / \mathrm{C}$ ratios. In the beginning (until day 2), low $\mathrm{O} / \mathrm{C}$ values were observed and indicated the decomposition of labile fraction. High $\mathrm{O} / \mathrm{C}$ values in the detritus mineralization occurred after consumption of labile fractions (from the second to ninth day), thus oxidation of refractory substances is assumed to be responsible for this. After that, we observed a decrease in the $\mathrm{O} / \mathrm{C}$ ratios, due to availability of labile compounds from alterations of refractory organic matter. Cunha-Santino et al., (2004) also showed similar results and indicated that $\mathrm{O} / \mathrm{C}$ temporal changes reflect the detritus chemical composition and their transformations.

$\mathrm{CO}_{2}$ formation and oxygen consumption in water column in freshwater ecosystems are important for determination of the aquatic metabolism (Carmouze et al., 1991). In function of global change, $\mathrm{CO}_{2}$ dynamics has high importance in aquatic ecosystems studies, such as coastal lagoons (Marotta et al., 2010). The results in the present research suggested that initial stage decomposition of emergent aquatic macrophytes, such as $T$. domingensis and E. interstincta, in water column do not have relevance on $\mathrm{CO}_{2}$ formation in Cabiúnas lagoon (Figure 6), considering the temperature of the study $\left(22 \pm 2{ }^{\circ} \mathrm{C}\right)$, which was similar to the average temperature observed in the lagoon from July 2000 to February 2003 (Enrich-Prast et al., 2004). However, the high biomass in the stands of these aquatic macrophytes and accumulated POC can enable intense $\mathrm{O}_{2}$ uptake, potentiating anaerobic process, like methanogenesis in sedimentwater interface. High methane concentrations in sediments of littoral region colonized by aquatic macrophytes in Cabiúnas lagoon can confirm this statement (Fonseca et al. 2004; Petruzella et al., 2013). This demonstrates the importance of this compartment in the stock and cycling of the emergent aquatic macrophytes particulate organic matter.

In conclusion, our results confirm the aerobic decomposition in the initial stages is higher only in $T$. domingensis mineralization. Oxygen consumption varies according to the alterations in the chemical composition of the detritus during decomposition. The formation of $\mathrm{CO}_{2}$ from $T$. domingensis and E. interstincta decomposition in the water column is irrelevant in Cabiúnas Lagoon. The low DOC release from fresh aquatic macrophytes detritus indicates that particulate organic matter mineralization is the main route of $T$. domingensis and E. interstincta decomposition. 


\section{Acknowledgements}

The authors thank NUPEM/UFRJ by logistical support, CNPq and PETROBRAS for financial support to Long Term Ecological Research program (LTER) and EcoLagoas project, respectively. We also thank Adriana de Melo Rocha for improvement in English.

\section{References}

ALVAREZ, S. and GUERRERO, MC. 2000. Enzymatic activities associated with decomposition of particulate organic matter in two shallow ponds. Soil Biology and Biochemistry, vol. 32, p. 1941-1951. http://dx.doi. org/10.1016/S0038-0717(00)00170-X

AMADO, AM., ESTEVES, FA., FIGUEIREDOBARROS, MP. and SANTOS, AM. 2005. Shortterm and seasonal effects of water level variations on Eleocharis interstincta (VAHL) nutrient content in a tropical coastal lagoon. Acta Limnologica Brasiliensia, vol. 17, no. 1, p. 91-99.

BIANCHINI JUNIOR, I. 2003. Modelos de crescimento e decomposição de macrófitas aquáticas. In THOMAZ, SM. and BINI, LM., eds. Ecologia e manejo de macrófitas aquáticas. Maringá: EdUEM. $341 \mathrm{p}$.

BIANCHINI JUNIOR, I. and CUNHA-SANTINO, MB. 2008. As rotas de liberação do carbono dos detritos de macrófitas aquáticas. Oecologia Brasiliensis, vol. 12, no. 1, p. 20-29. http://dx.doi.org/10.4257/ oeco.2008.1201.03

BIANCHINI JUNIOR, I., CUNHA-SANTINO, MB. and PERET, AM. 2008. Oxygen demand during mineralization of aquatic macrophytes from an oxbow lake. Brazilian Journal of Biology, vol. 68, no. 1, p. 61-67. http://dx.doi.org/10.1590/S151969842008000100009

BIANCHINI JUNIOR, I., PACOBAHYBA, LD. and CUNHA-SANTINO, MB. 2002. Aerobic and anaerobic decomposition of Montrichardia arborescens (L.) Schott. Acta Limnologica Brasiliensia, vol. 14, no. 3, p. 27-34.

BREZONIK, PL. 1993. Chemical kinetics and process dynamics in aquatic systems. Boca Raton: Lewis. 754 p.

BRUM, PR. and ESTEVES, FA. 2001. Changes in abundance and biomass of the attached bacterial community throughout the decomposition of three species of aquatic macrophytes. Oecologia Brasiliensis, vol. 9, no. 1, p. 77-96. http://dx.doi.org/10.4257/ oeco.2001.0901.07

BRUM, PR., FARJALLA, VF., GONÇALVES JUNIOR, JF., SANTOS, AM., PÔRTO, MT., VIEIRA, EDR., FERREIRA, FM. and BIANCHINI JUNIOR, I. 1999. Aspects of uptake of dissolved oxygen in Cabiúnas and Imboassica lagoons (Macaé, RJ). Brazilian Archives of Biology and Technology, vol. 42, p. 433-440.
CAMPBELL, CA. 1978. Soil organic carbon, nitrogen and fertility. In SCHNITZER, M. and KHAN, SU., eds. Development in soil science 8: Soil organic matter. Amsterdam, Oxford, New York: Elsevier. 319 p.

CARMOUZE, JP., KNOPPERS, B. and VASCONCELOS, P. 1991. Metabolism of a subtropical Brazilian lagoon. Biogeochemistry, vol. 14, p. 129-148.

CHIMNEY, MJ. and PIETRO, KC. 2006. Decomposition of macrophyte litter in a subtropical constructed wetland in south Florida (USA). Ecological Engineering, vol. 27, p. 301-321. http:// dx.doi.org/10.1016/j.ecoleng.2006.05.016

COSTANTINI, ML., ROSSI, L., FAZI, S. and ROSSI, D. 2009. Detritus accumulation and decomposition in a coastal lake (Acquatina-southern Italy). Aquatic Conservation: Marine and freshwater ecosystems, vol. 19 , p. 566-574.

CUNHA-SANTINO, MB. and BIANCHINI JUNIOR, I. 2006. The aerobic and anaerobic decomposition of Typha domingensis Pers. Acta Limnologica Brasiliensia, vol. 18, no. 3, p. 321-334.

CUNHA-SANTINO, MB., PACOBAHYBA, LD. and BIANCHINI JUNIOR, I. 2004. O/C Stoichiometry from mineralization of Montrichardia arborescens (L.) Schott. Acta Limnologica Brasiliensia, vol. 16, no. 4, p. 351-357.

DEBUSK, TA. and DIERBERG, FE. 1984. The effect of nitrogen and fiber content on the decomposition of the water hyacinth (Eichhornia crassipes [Mart.] Solms). Hydrobiologia, vol. 118, p. 199-204. http:// dx.doi.org/10.1007/BF00021043

ENRICH-PRAST, A., BOZELLI, RL., ESTEVES, FA. and MEIRELLES, FP. 2004. Lagoas costeiras da Restinga de Jurubatiba: descrição de suas variáveis limnológicas. In ROCHA, CFD., ESTEVES FA. and SCARANO, FR., orgs. Pesquisas de longa duração na Restinga de Jurubatiba: ecologia, história natural e conservação. São Carlos: RiMa. 475 p.

FAGERBAKKE, K., HELDAL, M. and NORLAND, S. 1996. Content of carbon, nitrogen, oxygen, sulfur and phosphorus in native aquatic and cultured bacteria. Aquatic Microbial Ecology, vol. 10, p. 15-27. http://dx.doi.org/10.3354/ame010015

FARIA, BM. and ESTEVES, FA. 2000. Carbono orgânico nas lagoas costeiras do Norte Fluminense: origem, degradaçáo e transferência para a cadeia trófica. In ESTEVES, FA. and LACERDA, LD., eds. Ecologia de restingas e lagoas costeiras. Macaé: NUPEM. 446 p.

FARJALLA, VF. 1998. Nutrientes limitantes ao crescimento do bacterioplâncton nas lagoas Carapebus, Comprida, Cabiúnas e Iodada. In ESTEVES, FA., ed. Ecologia das lagoas costeiras do Parque Nacional da Restinga de Jurubatiba e do Municipio de Macaé (RJ). Macaé: NUPEM. 464 p.

FARJALLA, VF, MARINHO, CC. and ESTEVES, FA. 1999. The uptake of oxygen in the initial stages of 
decomposition of aquatic macrophytes and detritus from terrestrial vegetation in a tropical coastal lagoon. Acta Limnologica Brasiliensia, vol. 11, p. 185-193.

FARJALLA, VF., MARINHO, CC., FARIA, BM., AMADO, AM., ESTEVES, FA., BOZELLI, RL. and GIROLDO, D. 2009. Synergy of fresh and accumulated organic matter to bacterial growth. Microbial Ecology, vol. 57, p. 657-666. PMid:18985269. http://dx.doi.org/10.1007/ s00248-008-9466-8

FONSECA, ALS., MINELLO, M., MARINHO, CC. and ESTEVES, FA. 2004. Methane concentration in water column and in pore water of a coastal lagoon (Cabiúnas Lagoon, Macaé, RJ, Brazil). Brazilian Archives of Biology and Technology, vol. 47, no. 2, p. 301-308.

GEURTS, JJM., SMOLDERS, AJP., BANACH, AM., VAN DE GRAAF, JPM., ROELOFS, JGM. and LAMERS, LPM. 2010. The interaction between decomposition, net $\mathrm{N}$ and $\mathrm{P}$ mineralization and their mobilization to the surface water in fens. Water Research, vol. 44, p 3487-3495.

GODSHALK, GL. and WETZEL, RG. 1978a. Decomposition of aquatic angiosperms. I. Dissolved components. Aquatic Botany, vol. 5, p. 281-300. http://dx.doi.org/10.1016/0304-3770(78)90073-6

GODSHALK, GL. and WETZEL, RG. 1978 b. Decomposition of aquatic angiosperms. II. Particulate components. Aquatic Botany, vol. 5, p. 301-327. http://dx.doi.org/10.1016/0304-3770(78)90074-8

GONÇALVES, JF., SANTOS AM. and ESTEVES, FA. 2004. The influence of the chemical composition of Typha domingensis and Nymphaea ampla detritus on invertebrate colonization during decomposition in a Brazilian coastal lagoon. Hydrobiologia, vol. 527, p. 125-137. http://dx.doi.org/10.1023/ B:HYDR.0000043190.49651.dc

GOPAL, B. 1984. Comparison of leaching losses from decomposing litter of the terrestrial and marsh plants on land and in water. Verhandlungen des Internationalen Verein Limnologie, vol. 22, p. 947 950.

HENRIQUES, RPB., ARAUJO, DSD., ESTEVES, FA. and FRANCO AC. 1988. Análise preliminar das comunidades de macrófitas aquáticas da Lagoa Cabiúnas, Rio de Janeiro, Brasil. Acta Limnologica Brasiliensia, vol. 2, p. 783-802.

JANSSEN, MJ. and WALKER, KFW. 1999. Processing of wetland and riparian plant litter in the River Murray, South Australia. Hydrobiologia, vol. 411, p. 53-64. http://dx.doi.org/10.1023/A:1003891720922

KNOPPERS, B. 1994. Aquatic primary production in coastal lagoons. In KJERFVE, B., ed. Coastal Lagoon Processes, vol. 60. Amsterdam: Elsevier Oceanography Series. 577 p. http://dx.doi.org/10.1016/S04229894(08)70014-X

KRISTENSEN, E., AHMED, SI. and DEVOL, AH. 1995. Aerobic and anaerobic decomposition of organic matter in marine sediment: Which is fastest? Limnology and Oceanography, vol. 40, no. 8, p. 14301437. http://dx.doi.org/10.4319/lo.1995.40.8.1430

LECERF, A., RISNOVEANU, G., POPESCU, C., GESSNER, MO. and CHAUVET, E. 2007. Decomposition of diverse litter mixtures in streams. Ecology, vol. 88, p. 219-227. http://dx.doi. org/10.1890/0012-9658(2007)88[219:DODLMI ]2.0.CO;2

LI, X., CUI, B., YANG, Q., TIAN, H., LAN, Y., WANG, T. and HAN, Z. 2012. Detritus quality controls macrophyte decomposition under different nutrient concentrations in a eutrophic shallow lake, North China. PLoS ONE, vol. 7, no. 7, p. 1-10.

MAIE, N., JAFFÉ, R., MIYOSHI, T. and CHILDERS, DL. 2006. Quantitative and qualitative aspects of dissolved organic carbon leached from senescent plants in an oligotrophic wetland. Biogeochemistry, vol. 78, p. 285-314. http://dx.doi.org/10.1007/ s10533-005-4329-6

MARINHO, CC., MEIRELLES-PEREIRA, F., GRIPP, AR., GUIMARÃES, CC., ESTEVES FA. and BOZELLI, RL. 2010. Aquatic macrophytes drive sediment stoichiometry and the suspended particulate organic carbon composition of a tropical coastal lagoon. Acta Limnologica Brasiliensia, vol. 22, no. 2, p. 208-217.

MAROTTA, H., DUARTE, CM., PINHO, L. and ENRICH-PRAST, A. 2010. Rainfall leads to increased pCO2 in Brazilian coastal lakes. Biogeosciences, vol. 7, p. 1607-1614. http://dx.doi. org/10.5194/bg-7-1607-2010

McLATCHEY, GP. and REDDY, KR. 1998. Regulation of organic matter decomposition and nutrient release in a wetland soil. Journal of Environmental Quality, vol. 17, p. 1268-1274.

MOORE JUNIOR, PA., REDDY, KR. and GRAETZ, DA. 1992. Nutrient transformations in sediments influenced by oxygen supply. Journal of Environmental Quality, vol. 21, p. 387-393. http://dx.doi. org/10.2134/jeq1992.00472425002100030014x

PANOSSO, RF., ATTAYDE, JL. and MUEHE, D. 1998. Morfometria das lagoas Imboassica, Cabiúnas, Comprida e Carapebus: Implicaçóes para seu funcionamento e manejo. In ESTEVES, FA., ed. Ecologia das lagoas costeiras do Parque Nacional da Restinga de Jurubatiba e do Município de Macaé (RJ). Macaé: NUPEM. 464 p.

PERET, AM. and BIANCHINI JUNIOR, I. 2004. Stoichiometry of aerobic mineralization $(\mathrm{O} / \mathrm{C})$ of aquatic macrophytes leachate from a tropical lagoon (São Paulo - Brazil). Hydrobiologia, vol. 528, p. 167 178. http://dx.doi.org/10.1007/s10750-004-2340-x

PETRUZELLA, A., MARINHO,CC., SANCHES,LF., MINELLO, M. and ESTEVES, FA. 2013. Magnitude and variability of methane production and concentration in tropical coastal lagoons sediments . Acta Limnologica Brasiliensia. No prelo. 
PIECZYNSKA, E. 1993. Detritus and nutrient dynamics in the shore zone of lakes: a review. Hydrobiologia, vol. 251, p. 49-58. http://dx.doi.org/10.1007/ BF00007164

QUALLS, RG. and RICHARDSON, CJ. 2003. Factors controlling concentration, export, and decomposition of dissolved organic nutrients in the Everglades of Florida. Biogeochemistry, vol. 62, p. 197-229. http:// dx.doi.org/10.1023/A:1021150503664

REDDY, KR. and SACCO, PD. 1981. Decomposition of water hyacinth in agricultural drainage water. Journal of Environmental Quality, vol. 10, no. 2, p. 228-234. http://dx.doi.org/10.2134/ jeq1981.00472425001000020022x

ROLAND, F. 1998. Produçấo fitoplanctônica em diferentes classes de tamanho nas lagoas Imboassica e Cabiúnas. In ESTEVES, FA., ed. Ecologia das lagoas costeiras do Parque Nacional da Restinga de Jurubatiba e do Município de Macaé (RJ). Macaé: NUPEM. 464 p.

SANTOS, AM., AMADO, AM., MINELLO, M., FARJALLA, VF. and ESTEVES, FA. 2006. Effects of the sand bar breaching on Typha domingensis (PERS.) in a tropical coastal lagoon. Hydrobiologia, vol. 556, p. 61-68. http://dx.doi.org/10.1007/s10750-005$1084-6$

SCHLICKEISEN, E., TIETJEN, TE., ARSUFFI, TL. and GROEGER, AW. 2003. Detritus processing and microbial dynamics of an aquatic macrophyte and terrestrial leaf in a thermally constant, springfed stream. Microbial Ecology, vol. 45, p. 411-418. PMid:12704561. http://dx.doi.org/10.1007/ s00248-002-1062-8

SILVA, RH., PANHOTA, RS. and BIANCHINI JUNIOR, I. 2011. Aerobic and anaerobic mineralization of Salvinia molesta and Myriophyllum aquaticum leachates from a tropical reservoir (Brazil). Acta Limnologica Brasiliensia, vol. 23, no. 2, p. 109-118. http://dx.doi.org/10.1590/S2179975X2011000200001

WEBSTER, JR. and BENFIELD, EF. 1986. Vascular plant breakdown in freshwater ecosystems. Annual Review of Ecology and Systematics, vol. 17, p. 567-594. http://dx.doi.org/10.1146/annurev. es.17.110186.003031

Received: 10 April 2013 Accepted: 13 January 2014 